\title{
REGIONAL HUMAN CAPITAL DISEQUILIBRIA: THE CASE OF YOUTH MIGRATION IN LATVIA
}

\section{Reǵionālā cilvēkkapitāla nelīdzsarotība: Latvijas jauniešu migrācija Latvijā}

\author{
Elina Apsite-Berina, Girts Burgmanis, Laura Prusakova \\ University of Latvia, Faculty of Geography and Earth Sciences \\ e-mail: elina.apsite-berina@lu.lv
}

\begin{abstract}
Riga stands out within Latvia as a significant pool of economic and education-related opportunities. Students and young people are traditionally more mobile and move towards destinations where self-advancement is accessible. Thus, this study aims to describe the human capital disequilibria in the regions of Latvia by analysing youth in the age group from 15 to 34 years and making a comparison between the years 2011 and 2018. The backbone of the study is an analysis of changes in regional unemployment rates and changes in the number of young people in certain regions outside the capital, as well as the general trend for the proportion of young people to decrease in some regions since 2011. The main research questions addressed are: how can the core-periphery model be applied to the regions of Latvia, and to what extent do economic opportunities explain regional inequality? The results indicate that Riga is a core, geographically, and the functionally related regions of Pieriga and Zemgale are semi-peripheral regions. However, the regions of Vidzeme, Latgale and Kurzeme are "places of lower rank" or peripheral regions, which are losing young people in the competition both with the core areas within the country and with other attractive destinations abroad.
\end{abstract}

Keywords: youth mobility, regions, unemployment, youth population, Latvia

DOI: $10.22364 / \mathrm{fg} .18 .4$

\section{Introduction}

Economic development and success for countries and regions largely depends on human capital resources. Young people are an essential asset for, firstly, the sustainability of the educational system; secondly, the sustainability of the employment system; and, thirdly, for demographic stability and reproduction. Thus the migration flows of youth have become an important field of research for various stakeholders in understanding the push and pull factors for youth migration and in developing solutions for demographic issues. Considering that migration outcomes are scale-specific, it is very important to focus on regions, and in some cases on subregions within them. The regional dimension is particularly relevant but often neglected: for example, Bartlett and Prica (2013) show evidence of the existence of core regions, peripheral regions and super-peripheral regions, while King et al. (2014) establish a relationship between the position of the region, and migration and mobility patterns.

There are numerous studies on core-periphery relationships within the EU (Pain 2008; Magone et al. 2016; Lulle 2019; King 2019). Traditionally, the coreperiphery model is described through the ongoing process of uneven economic 
opportunities and the formation of specific social and political conditions (King 2019) drawing potential migrants to more prosperous spatial units. It has long since been discovered and re-examined that power relation between core and peripheral territories are asymmetrical and increase social inequality (Seers 1979; King 2015; King 2019).

The British human geographer Russell King provides a categorisation of the core-periphery model within the EU. He firstly points to the importance of information flows, which are directed from the central parts to the more distant ones at the same time as a counter-flow of geographic mobility takes place from the peripheries to regional economic centres. Thus, according to Kuus, peripheries are "places of lower rank" (Kuus 2013; Lulle 2019).

Studies have also been done on the Baltic region. The case of the core and periphery relationships among the regions in Europe has been examined (Lulle 2019), categorisation of the regions has been carried out by looking at socio-economic disparities (Kebza 2019), regional demography in Latvia has been examined (Krisjane and Krumins 2019; Krumins et al. 2020), migration trends to and from the regions of Latvia have been studied (Krisjane and Bauls 2007), changing patterns of urban migration in Latvia have been highlighted (Krisjane et al. 2010), geographical mobility of the workforce in Latvia has been studied (Krisjane et al. 2007), labourspecific problems of the labour market in regions of Latvia have been examined (LLU 2007), and the capacity of the regions has been studied, taking into account regional economic activity in the period 1999 to 2004 (Zobena 2005).

It is also vital to examine the role of each region; thus, the idea of escalator regions has been explored. The central hypothesis of the escalator region (Fielding 1994; Champion 2011) lies in the idea that these regions offer better labour market opportunities as well as income levels compared to other regions without such opportunities. In-migrants to those regions can obtain faster career growth than elsewhere (Ham et al. 2012). The model consists of three stages, the last of which is devoted to the stepping off the escalator strategy, which most often is related to personal priorities at that particular life stage. Later, the idea of the "escalator effect" (Gordon et al. 2015) was elaborated, which refers to migrants residing in particular regions or urban agglomerations experiencing a rapid increase in the size of the labour market. The effect involves wage growth, accumulation of human capital and job matching (Velthuis et al. 2019, Gordon et al. 2015; Newbolt 2015; Glaeser and Mare 2001).

At a more detailed scale, there are short-term and long-term implications for regions of in-migration and out-migration. Of particular importance are the net human capital outcomes (brain gain, brain drain, etc.), as well as longer-term demographic stability and sustainable birth rates.

While necessary for individuals, the mobility of young people has significant implications for the efficient labour market system and for regional disequilibria.

In order to see if Latvia is currently characterised by regional disequilibria and to test the core-periphery model, the following research questions are considered: 
1. How could the core-periphery model be applied in the case of Latvia and to what extent does it explain regional disequilibria?

2. Does regional inequality in economic opportunities influence youth migration in Latvia?

\section{Data and methods}

The study carries out an analysis of the officially available data on the youth population in Latvia. The analysed data sets cover persons aged 15 to 34, and the economic activity and unemployment rates of this age group in the different regions of Latvia. We also used the main trends in emigration and immigration. In addition, the average monthly salary by region was used to see the influence of economic opportunities. This study makes use of the official statistics provided by the Central Statistical Bureau of Latvia. In this analysis, we consider and compare the years 2011 and 2018.

The framework of the data analysis consists of 1) a comparison of the youth population, employability and migration in the years 2011 and 2018 in the different regions of Latvia; 2) a geographical visualisation of youth unemployment and youth mobility in regions of Latvia; 3) a geographical comparison of average monthly salaries in the years 2011 and 2018.

\section{Results: Geographical aspects of youth dynamics and employability in the region}

In the last three decades, a negative natural growth and migration rate has significantly changed the demographic structure of Latvia. The number of people aged 15-34 in Latvia has continuously dropping by nearly 50\%. Table 1 shows that in the seven years from 2011 to 2018, the number of young people decreased by 109,738 in total, or nearly by $20 \%$. The rapid decrease of young people in the last seven years also reflects changes among economically active people in the age group 15-34. From 2011 to 2018, the number of economically active young people decreased by 61,670 people or by $17 \%$. The largest decrease of young people in total numbers was observed in the largest statistical region of Latvia - Riga region. The Riga region had the most active migration processes as well. Although net migration from 2011 to 2018 was negative, the number of young people aged 15-34 moving to the region $(15,907)$ was nearly the same as to all other regions combined $(16,650)$. At the same time, the number of young people migrating away from Riga region $(26,039)$ was at least two times less than from all other regions combined $(56,231)$. 
Table 1. Youth population aged 15-34, employability, and migration in the year 2011 and 2018 by region (based on Central Statistical Bureau of Latvia data)

\begin{tabular}{|l|l|l|l|l|l|l|}
\hline & $\begin{array}{l}\text { Riga } \\
\text { region }\end{array}$ & $\begin{array}{l}\text { Pieriga } \\
\text { region }\end{array}$ & $\begin{array}{l}\text { Vidzeme } \\
\text { region }\end{array}$ & $\begin{array}{l}\text { Kurzeme } \\
\text { region }\end{array}$ & $\begin{array}{l}\text { Zemgale } \\
\text { region }\end{array}$ & $\begin{array}{l}\text { Latgale } \\
\text { region }\end{array}$ \\
\hline Youth population & & & & & & \\
\hline 2011 & 183,914 & 102,248 & 56,945 & 71,767 & 70,166 & 76,041 \\
\hline 2018 & 151,628 & 84,234 & 45,198 & 57,006 & 55,611 & 57,666 \\
\hline Growth & $-32,286$ & $-18,014$ & $-11,747$ & $-14,761$ & $-14,555$ & $-18,375$ \\
\hline Youth employment & & & & & & \\
\hline $\begin{array}{l}\text { Economically active } \\
2011\end{array}$ & 132,236 & 69,047 & 32,304 & 43,368 & 46,533 & 46,729 \\
\hline $\begin{array}{l}\text { Economically active } \\
2018\end{array}$ & 112,287 & 58,778 & 28,554 & 36,295 & 38,810 & 33,823 \\
\hline Unemployed 2011 & 32,534 & 15,527 & 7,129 & 9,290 & 12,680 & 12,372 \\
\hline Unemployed 2018 & 9,479 & 48,25 & 3,289 & 4,174 & 3,880 & 5,906 \\
\hline Growth & $-23,055$ & $-10,702$ & $-3,840$ & $-5,116$ & $-8,800$ & $-6,466$ \\
\hline Youth mobility & \multicolumn{7}{|l|}{} & & & & \\
\hline Immigration 2011-2018 & 15,907 & 4,483 & 2,378 & 3,284 & 3,012 & 3,493 \\
\hline Emigration 2011-2018 & 26,039 & 11,492 & 8,710 & 12,754 & 9,203 & 14,072 \\
\hline $\begin{array}{l}\text { Net migration } \\
2011-2018\end{array}$ & $-10,132$ & $-7,009$ & $-6,332$ & $-9,470$ & $-6,191$ & $-10,579$ \\
\hline & & & & & & \\
\hline
\end{tabular}

These results are not surprising, because according to the core-periphery model developed by King (King 2019), we assume that the Riga region corresponds to the core region, which works in two ways. Firstly, as the economic service centre of Latvia, it attracts youth from all other regions of Latvia as well as from abroad for study purposes. Secondly, the higher economic opportunities - including job opportunities - in Riga attract young people who stay there after their studies in Riga and also those who move to Riga after graduation from a peripheral region with fewer opportunities (e.g., Latgale). Our assumption is partly confirmed by the fast recovery of Riga region after the global economic crisis from 2008 to 2012: i.e., between 2011 and 2018 the number of unemployed youth aged 15-34 decreased rapidly - by more than three times (3.4). Moreover, the regions of Pieriga and Zemgale are functionally linked to the core region and show similar patterns of unemployment change (e.g., in both regions the number of unemployed youth decreased by more than three times 3.2), but the less active in-migration processes there correspond to semi-peripheral regions. The regions of Latgale, Vidzeme and Kurzeme, which are more functionally separated from the core region in our study, correspond to peripheral regions according to King's model. After the economic crisis, the number of unemployed young people in all three regions decreased by no more than 2.2 times and the substantial domination of emigration over immigration characterises Kurzeme, Latgale and Vidzeme: i.e., four (for Latgale) or nearly four times more young people moved away from than moved to those regions between 2011 and 2018. 


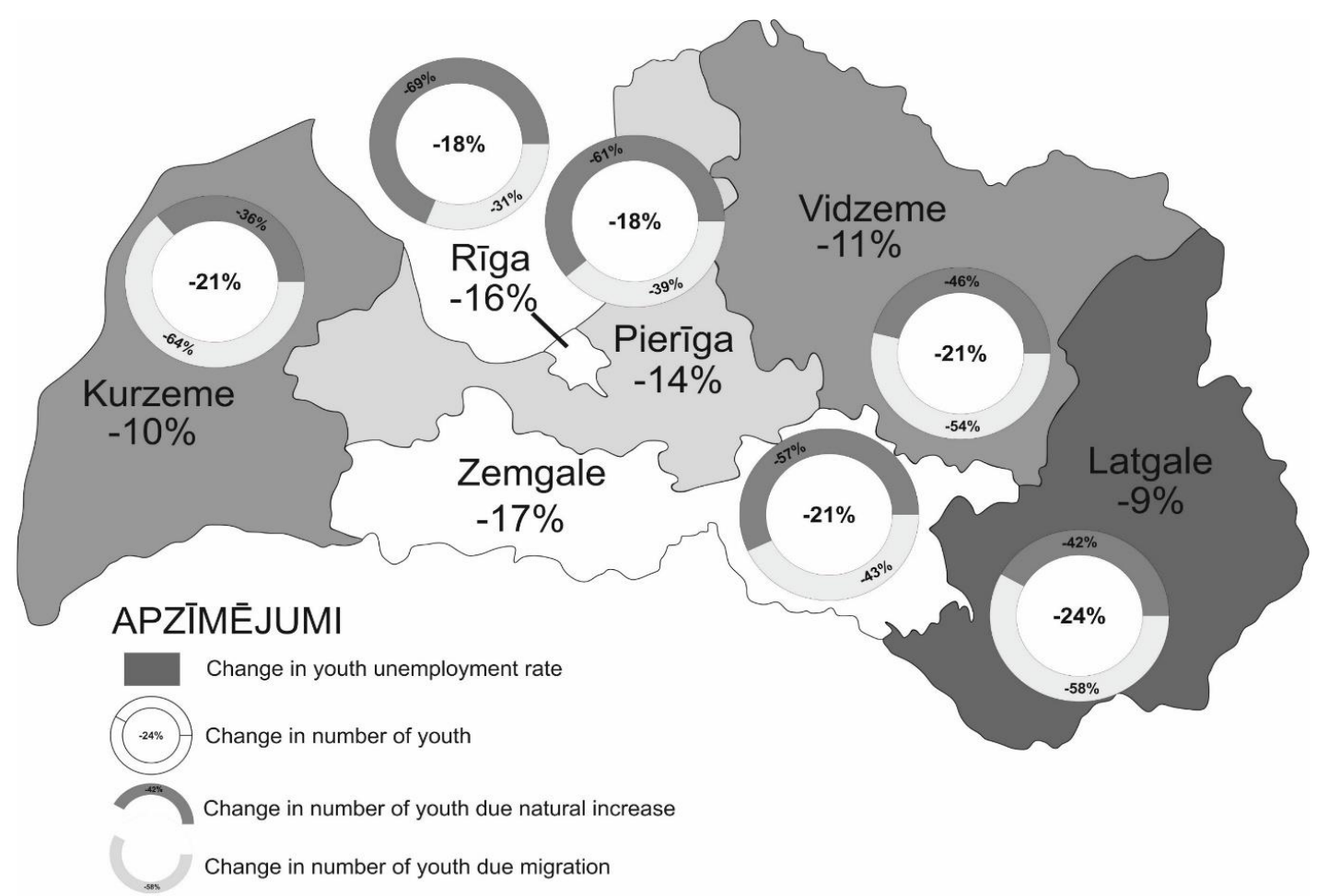

Figure 1. Regional youth unemployment and youth mobility comparison in regions in

2011 and 2018 (authors' figure based on Central Statistical Bureau of Latvia)

A more detailed analysis of the data and the use of comparative indicators (Figure 1) confirmed our assumption. It revealed that the features of peripheral regions, including fewer jobs and education opportunities and lower wages, explain the domination of migration processes over negative natural growth in Vidzeme, Kurzeme and Latgale. For example, the youth unemployment rate from 2011 to 2018 in all three regions decreased less than in the previously suggested core region (Riga) and the semi-peripheral regions (Pieriga and Zemgale). At the same time in Vidzeme, Kurzeme and Latgale, the greater total decrease in the number of young people Vidzeme and Kurzeme - 21\%; Latgale - 24\% between 2011 and 2018 was due to negative net migration, i.e., in all three regions 54 to $64 \%$ of the total decrease of the number of young people was due to the domination of emigration over immigration. In the core region - Riga - where the decrease in the unemployment rate was more pronounced $(-16 \%)$ the share of net migration in the total decrease of the youth population in the region $(-18 \%)$ was significantly less: $-31 \%$. Similar patterns, although less pronounced, can be seen in Pieriga and Zemgale - regions suggested by our model as being semi-peripheral regions. Both regions saw a similar decrease in the youth unemployment rate (Pieriga -14\%; Zemgale -17\%) and a prevalence of natural growth (Pieriga $-61 \%$; Zemgale $-57 \%$ ) over net migration (Pieriga -39\%; Zemgale $43 \%$ ) and the total decrease of the number of young people in the region (Pieriga $18 \%$; Zemgale $-21 \%$ ). 
Table 2. Average monthly gross salary by regions, 2011 and 2018 (based on Central

Statistical Bureau of Latvia data)

\begin{tabular}{|c|c|c|c|c|c|c|}
\hline Year/Region & Riga region & $\begin{array}{c}\text { Pieriga } \\
\text { region }\end{array}$ & $\begin{array}{c}\text { Vidzeme } \\
\text { region }\end{array}$ & $\begin{array}{c}\text { Kurzeme } \\
\text { region }\end{array}$ & $\begin{array}{c}\text { Zemgale } \\
\text { region }\end{array}$ & $\begin{array}{c}\text { Latgale } \\
\text { region }\end{array}$ \\
\hline 2011 & 757 & 622 & 518 & 559 & 547 & 468 \\
\hline 2018 & 1129 & 949 & 803 & 858 & 848 & 701 \\
\hline \multicolumn{2}{|r|}{ Compared to Riga region in 2011 } & $82 \%$ & $68 \%$ & $74 \%$ & $72 \%$ & $62 \%$ \\
\hline \multicolumn{2}{l}{ Compared to Riga region in 2018 } & $84 \%$ & $71 \%$ & $76 \%$ & $75 \%$ & $62 \%$ \\
\hline
\end{tabular}

Although the evidence from Table 2 only partly complements our coreperiphery model, it does, however, support the hypothesis included in the model that in regions with less economic opportunities, emigration will predominate over immigration. The data clearly shows that the low monthly salaries in Latgale compared to Riga region in 2011 and 2018 did not only have a general effect on the decrease in the youth population (-24\%) from 2011 to 2018 but also on the predominance of the net migration rate $(-58 \%)$ over the natural growth rate $(-42 \%)$ in the total decrease of the number of young people in the region. We can observe similar patterns in Vidzeme, where the average monthly salary is the second lowest in Latvia and where migration processes predominate over natural growth in the total decrease in the number of young people in the region. The evidence from Table 2 shows that further work and more detailed analysis is necessary to explain the case of Kurzeme according to the core-periphery model. Although the average monthly salary in Kurzeme region in 2011 and 2018 is the third-highest in Latvia; however, the majority of the total decrease of the number of youth in the region is due to the higher net migration of youth (-64\%) compared to other regions in Latvia. Finally, the mean monthly salaries in Pieriga and Zemgale also confirm that both regions correspond to semi-peripheral regions. The difference in average monthly salary between Riga and both semi-peripheral regions (no more than 25\%) in 2018 reflects a higher share of net migration in the total decrease of the number of young people in both regions than in Riga, but significantly less than in the peripheral regions, Vidzeme and Latgale.

\section{Conclusions}

Our results show that the core-periphery model can be applied in the case of Latvia. Three leading indicators were used to compare regions and to develop the core-periphery model: 1) share of net youth migration in the total decrease of young people; 2) changes in the youth unemployment rate; 3) the average monthly gross salary. The results indicate that Riga can be identified as the core. In Riga the share of net youth migration in the total decrease of young people is the smallest of all the regions $(-31 \%)$. Riga region also had the highest average monthly gross salaries in 2011 and 2018 and the second-highest decrease in the unemployment rate between 2011 and 2018 (-16\%). Our evidence shows that regions that are geographically and functionally related to Riga - Pieriga and Zemgale are to semi-periphery. The share of net youth migration in the total decrease of youth for both regions is less than $50 \%$; the 
decrease in the youth unemployment rate is similar to Riga (more than -14\%), and average monthly gross salaries differ from Riga by no more than $25 \%$. We assume that Vidzeme, Latgale and Kurzeme are "places of lower rank" or peripheral regions which are losing their young population in the competition both with the core parts within the country and with other attractive destinations abroad. The average monthly gross salaries in Vidzeme and Latgale are more than 25\% lower than in Riga and the change in the unemployment rate from 2011 to 2018 was no more than $-11 \%$ in all three regions.

Finally, the evidence from these results clearly shows that out-migration of youth from regions is tightly linked with opportunities for employment and higher salaries. Respectively, out-migration is higher in regions where the decrease in the youth unemployment rate is lower and where at the same time salaries are lower compared to the core region. Furthermore, our study suggests that a threshold of $50 \%$ in the share of youth net migration in the total decrease of young people - i.e. that migration processes are predominating over natural growth - is useful in making a distinction between core and semi-peripheral regions and peripheral regions.

\section{Acknowledgement}

This study was supported by ERDF grant 1.1.1.2/VIAA/1/16/184.

\section{Kopsavilkums}

Rīga un tās apkārtne koncentrē nozīmīgu ekonomisko un ar izglīîibu saistīto iespēju kopumu, kas izceḷas Latvijas un arī Baltijas mērogā. Studenti un jaunieši tradicionāli ir mobilāki un bieži pārceḷas uz galamērķiem, kur saskata plašākas iespējas pašattīstībai. Tādējādi pētījuma mērḳis ir aprakstīt cilvēkkapitāla nelīdzsvarotību Latvijas reǵionos, analizējot jauniešu vecuma grupu no 15 līdz 34 gadiem un salīdzinot laika periodā no 2011. līdz 2018. gadam. Pētījuma pamatā ir analizētas reǵionālās bezdarba, jauniešu skaita pārmaiņas reǵionos, kā arī dažu reǵionu vispārējās jauniešu skaita samazināšanās tendences kopš 2011. gada. Galvenie pētījuma jautājumi ir: kā centra-perifērijas modeli var piemērot Latvijā un cik lielā mērā ekonomiskās iespējas izskaidro reǵionālo nevienlīdzību. Rezultāti norāda, ka ar Rīgu kā galveno, ǵeogrāfiski un funkcionāli saistītie reǵioni ir Pierīga un Zemgale, ko var uzskatīt par pus-perifēriju. Tomēr Vidzemes, Latgales un Kurzemes reǵioni ir "zemāka ranga vietas" vai perifērijas reǵioni, kas zaudē jauniešus konkurencē gan ar Rīgu, gan citiem pievilcīgiem galamērķiem ārvalstīs.

\section{References}

Beetz, S., Huning, S. and Plieninger, T. (2008). Landscapes of peripherization in North-Eastern Germany's countryside: New challenges for planning theory and practice. International Planning Studies, 13 (4), 295-310.

CSB (2019). Migration in Latvia. Unpublished data of Central Statistical Bureau of Latvia.

CSB (2020). Average Monthly gross salary. Published data: https://data.csb.gov.lv/pxweb/en/sociala/sociala_dsamaksa_isterm/DS090c.px (16.10 2020).

Glaeser, E. L. and Mare, D. C. (2001). Cities and skills. Journal of Labor Economics, 19 (2), 316342 . 
Gordon, I., Champion, T. and Coombes, M. (2015). Urban escalators and interregional elevators: The difference that location, mobility, and sectoral specialization make to occupational progression. Environment and Planning A, 47 (3), 588-606.

Kebza, M., Nováček, A., and Popjaková, D. (2019). Socio-Economic Disparities in the Baltic States: Analytical Comparison and Categorization of the Regions. Geographia Polonica, 92 (3), 289-307.

King, R. (2015). Migration and Southern Europe - A center-periphery dynamic? In: Baumeister, N. and Sala, R. (eds.) Southern Europe? Italy, Spain, Portugal and Greece from the 1950s to the Present Day. Frankfurt/New York: Campus, 139-169.

Krišjāne, Z. and Bauls, A. (2007). Migrācijas plūsmu reg̣ionālās iezīmes Latvijā. Paaudžu nomaiņa un migrācija Latvijā, Stratēgiskās analīzes komisijas zinātniski pētnieciskie raksti, 4 (15), 130-43.

Krišjāne, Z., and Krūmiņš, J. (eds.) (2019). Tautas ataudze Latvijā un sabiedrības atjaunošanas izaicinājumi. Rīga: Latvijas Universitātes Akadēmiskais apgāds.

Krišjāne, Z., Bērziņš, M. and Bauls A. (2010). Population concentration and de-concentration processes: changing urban migration pattern in Latvia. Proceedings of the Socio-Economic Spatial Systems and Territorial Governance Conference. Tartu, Estonia.

Krišjāne, Z., Eglīte, P., Bauls A, Lulle, A., Bērziņš, M., Brants, M., Cunska, Z., Gņedovska, I., Ivbulis, B., Krūzmētra, Z., Kūle, L., Markausa, I. M., Niklass, M., Pavlina, I., Titova, N., Vanaga, S., Vilciņš, A. and Zariņa, I. B. (2007). Darbaspēka geogrāfiskā mobilitāte. Rīga: Latvijas Universitāte, LR Labklājības ministrija.

Krumins, J., Berzins, A., and Dahs, A. (2020). Regional demographic trends in accordance with the new model of territorial division in Latvia and future dynamics in statistical regions of the Baltic States. Economic Science for Rural Development 2020, 233.

Kuus, M. (2013). Places of lower rank: Margins in conversations. Political Geography, 37, 30-32.

Latvijas Lauksaimniecības universitāte (2007). Latvijas un tās regionu darba tirgus specifiskās problèmas. Jelgava: SIA Jelgavas tipogrāfija.

Lulle, A. (2019). Balkans and Baltics: on migration as a factor of regional peripheralization. Journal of Balkan and Near Eastern Studies, 21 (1), 27-42.

Magone, J. M., Laffan, B. and Schweiger, C. (eds.) (2016). Core-periphery relations in the European Union: power and conflict in a dualist political economy. Routledge.

Newbold, B. (2015). Going Up? Canada's metropolitan areas and their role as escalators or elevators. Canadian Studies in Population, 42 (3/4), 49-62.

Pain, K. (2008). Examining 'core-periphery'relationships in a global city-region: the case of London and South East England. Regional Studies, 42 (8), 1161-1172.

Seers, D. (1979). The periphery of Europe. In: Seers, D., Shaffer, B. and Kiljunen, M.L. (eds.) Underdeveloped Europe: Studies in Core-Periphery Relations. Hassocks: The Harvester Press, 3-34.

Velthuis, S., Sissons, P., and Berkeley, N. (2019). Do low-paid workers benefit from the urban escalator? Evidence from British cities. Urban Studies, 56 (8), 1664-1680.

Zobena, A. (2005). Latvija. Pārskats par tautas attīstību 2004/2005: Rīcībspēja reǵgionos. LU Sociālo un politisko pētījumu institūts. 